\title{
THE AGE OF THE FERROPICRITIC VOLCANICS AND COMAGMATIC Ni-BEARING INTRUSIONS AT PECHENGA, KOLA PENINSULA, U.S.S.R.
}

\author{
EERO HANSKI, HANNU HUHMA, VALERY F. SMOLKIN and MATTI VAASJOKI
}

HANSKI, EERO; HUHMA, HANNU; SMOLKIN, VALERY F. and VAASJOKI, MATTI, 1990: The age of the ferropicritic volcanics and comagmatic Ni-bearing intrusions at Pechenga, Kola Peninsula, U.S.S.R. Bull. Geol. Soc. Finland, 62, Part 2, 123-133.

$\mathrm{Sm}-\mathrm{Nd}, \mathrm{Pb}-\mathrm{Pb}$ and $\mathrm{U}-\mathrm{Pb}$ isotopic results are presented for samples from the Pilgujärvi Suite of the Pechenga Series. Whole rock samples and clinopyroxenes of ferropicritic volcanics yield a Sm-Nd isochron age of $1990 \pm 66 \mathrm{Ma}$ with $\varepsilon_{\mathrm{Nd}}$ $+1.6 \pm 0.4$. This age is also supported by the $\mathrm{Pb}-\mathrm{Pb}$ data on ferropicrites, although the $\mathrm{Pb}$ isotopic system was partly disturbed by secondary processes. One $90 \%$ concordant $\mathrm{U}-\mathrm{Pb}$ zircon analysis from a felsic metasediment indicates a minimum age of $1970 \mathrm{Ma}$ for the deposition.

Our isotopic results along with previous geochemical data support the view that the ferropicritic volcanics and the Ni-bearing gabbro- wehrlite intrusions are coe$\mathrm{val}$ and have similar source characteristics. The calculated $\varepsilon_{\mathrm{Nd}}(1990 \mathrm{Ma})$ value of +1.6 suggests that the Pechenga ferropicrites previously had had a long-term depleted mantle source that experiended an enrichment event about $200 \mathrm{Ma}$ before the melt extraction occurred. Comparison with the previously presented Sm-Nd data from northern Finland, Sweden and Norway reveals differences in initial Nd isotopic ratios, which suggests a prolonged geochemical heterogeneity in the early Proterozoic subcontinental mantle below the Baltic Shield.

Key words: metavolcanic rocks, picrite, intrusions, absolute age, $\mathrm{Sm} / \mathrm{Nd}, \mathrm{U} / \mathrm{Pb}$, $\mathrm{Pb} / \mathrm{Pb}$, Proterozoic, Pechenga, Kola Peninsula, USSR.

Eero Hanski: Geological Survey of Finland, SF-96101 Rovaniemi, Finland Hannu Huhma and Matti Vaasjoki: Geological Survey of Finland, SF-02150 Espoo, Finland

Valery F. Smolkin: Academy of Sciences of the U.S.S.R., SU-184200 Apatity, U.S.S.R.

\section{Introduction}

Differentiated gabbro-clinopyroxenite-wehrlite intrusions are widely developed in the so-called "productive» tuffogene-sedimentary unit of the lower Proterozoic Pechenga (Petsamo) structure. The Pechenga Ni-Cu sulfide deposits are spatially and genetically related to these intrusions. According to Predovskii et al. (1974), the intrusions are comagmatic with picritic volcanic rocks of the younger South Pechenga Zone and hence there appears to be a considerable time gap between the emplacement of the intrusions and the deposition of the host sedimentary rocks. Such a view is in accord with the opinion of Gorbunov (1968) that the emplacement of the intrusions took place during the initial stages of folding of the area. In contrast, on the basis of geological, geochemical, and mineralogical investigations, Smolkin $(1977,1985)$ proposed a comagmatic relationship of the nickel-bearing intrusions and picritic volcanics of the Pechenga Series (North Pechenga 
Zone) and suggested that the emplacement of the intrusions occurred in the late stage of picritic volcanism after pronounced loss of volatiles of the magma. Consequently, the nickel-bearing intrusions and picritic volcanics were assigned to a single volcano-plutonic association. Relatively recently, a similar association has also been discovered and investigated in the central part of the Imandra-Varzuga structure (Smolkin and Dain 1985). Recent geochemical studies strongly support the close genetic relationship between the gabbro-wehrlite intrusions and ferropicritic volcanics (Hanski and Smolkin, 1989). Isotopic data based mainly on whole rock $\mathrm{Pb}-\mathrm{Pb}$ analyses have so far been inadequate to discriminate between the two views on the genetic relationship between the picritic volcanics and ore-bearing intrusions mentioned above.

To produce a precise age determination using the Sm-Nd method, the samples must fulfill three pre-requisites: they should be genetically related (have the same initial isotopic composition), have a sufficient compositional variation in parent/daughter ratios, and have been closed systems since crystallization for the elements considered. If primary magmatic minerals are unavailable, it may be difficult to find whole rock samples of basic/ultrabasic volcanics with sufficiently large variation in $\mathrm{Sm} / \mathrm{Nd}$ ratios (see Gruau et al. 1990). Ferropicritic volcanics at Pechenga are good candidates for Sm-Nd dating since they occur as strongly differentiated flows with rock types ranging from olivine-rich cumulates at the base through clinopyroxenites in the middle part to quench-textured gabbroic rocks in the upper part (Smolkin et al., 1987). Furthermore, clinopyroxene is in most samples partially or wholly preserved and can be separated for isotopic analyses.

We present in this article $\mathrm{Sm}-\mathrm{Nd}$ and $\mathrm{Pb}-\mathrm{Pb}$ isotopic results of whole rock and pyroxene samples of ferropicritic volcanics and pyroxene and apatite separates from one Ni-bearing intrusion. In addition, we have analysed $\mathrm{U}-\mathrm{Pb}$ isotopic composition of one zircon sample from a felsic metasediment spatially associated with ferropicritic volcanics.

\section{Regional geology}

The lower Proterozoic Pechenga structure comprises two zones: the Northern Zone and the Southern Zone which are separated by the major Poritash fault (Fig. 1). These zones are composed of rocks belonging to the Pechenga and South Pechenga Series, respectively. Rocks of the Pechenga Series have been penetrated by the Kola Superdeep Hole where their thickness reaches 6842 m (Kozlovsky 1987). They lie on an Archean basement with zircon ages of $2620-2640 \mathrm{Ma}$ (Kozlovsky 1987) and also cover the Mt. Generalskaya differentiated gabbro-norite intrusion which has a Sm-Nd age of $2453 \pm 42 \mathrm{Ma}$ (Bakushkin et al., in press). The Pechenga Series is subdivided into four suites (Ahmalahti, Kuetsjärvi, Kolasjoki and Pilgujärvi) each of which begins with sedimentary rocks and ends with a thicker pile of volcanic rocks (Fig. 1).

The sedimentary rocks are dominated by coarse clastic sediments and carbonates in the lower part of the section while phyllites and tuffites deposited in a deeper water environment prevail in the upper sedimentary units. The volcanic rocks change from andesites through alkalic basalts to tholeiitic basalts and minor picrites when going upwards in the section of the Pechenga Series.

The South Pechenga Series is composed of strongly deformed metasediments and metavolcanics. The latter vary in composition from picrites and tholeiitic basalts to andesites and rhyolites. The volcanism of this zone was terminated by the extrusion of porphyritic andesites at Poritash.

The upper age boundary for the formation of the Pechenga structure is provided by the emplacement age of the Litsa-Araguba granites. Pushkarev et al. (1978) report a U-Pb age of $1810 \pm 50 \mathrm{Ma}$ for zircons from these granites 


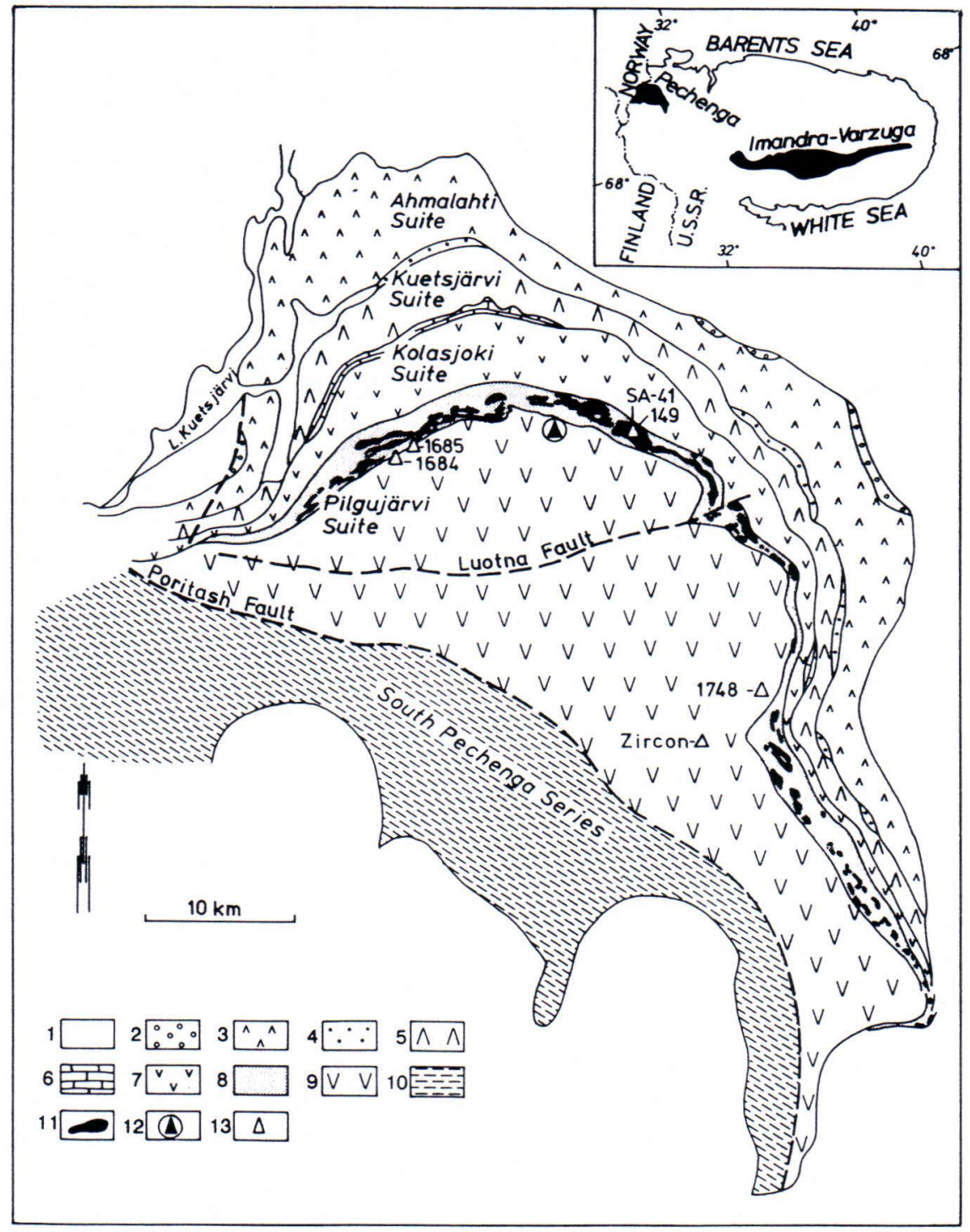

Fig. 1. Geological map of the Pechenga area simplified from Hanski and Smolkin (1989). Legend: 1, granitoids, migmatites, amphibolites; 2, 3, sedimentary and volcanic rocks of the Ahmalahti Suite; 4, 5, sedimentary and volcanic rocks of the Kuetsjärvi Suite; 6, 7, sedimentary and metavolcanic rocks of the Kolasjoki Suite; 8, 9, sedimentary and volcanic rocks of the Pilgujärvi Suite; 10, South Pechenga Series; 11, gabbro-wehrlite intrusions; 12, site of superdeep drilling; 13, sampling site of this work.

which (with respect to their composition and structural position) correspond to porphyritic granites in the Lake Inari area in northern Finland (Meriläinen 1976).

One of the most interesting features of the Pechenga area is the presence of iron-rich picrit- ic volcanics which Hanski and Smolkin (1989) called ferropicrites. They have been found at five stratigraphic levels: in the lower part of the Kolasjoki Suite, in the middle part of the "productive» unit together with Ni-bearing intrusions, and in the lower, middle, and upper parts 
of the overlying volcanic unit of the Pilgujärvi Suite where they are intercalated with tholeiitic volcanic rocks. Ferropicritic volcanics occur as tuffs (mostly of hyaloclastic nature), lavabreccias, pillow lavas, massive lavas, and thick, layered lava flows. The relative proportions of different modes of occurrence vary from level to level but a diminution of the amount of tuffs upwards in the section can be observed as a general trend. Ferropicritic volcanics of the fourth and, to a less degree, of the fifth level are associated with massive, rhytmically layered and brecciated tufosilitsites with turbidite-like structured beds.

About one quarter of the exposed area of the tuffogene-sedimentary unit of the Pilgujärvi Suite is occupied by gabbro-wehrlite intrusions which occur as relatively thin, often differentiated phacolith-like bodies with a maximum thickness of $500 \mathrm{~m}$. The intrusions and related $\mathrm{Ni}-\mathrm{Cu}$ sulfide deposits have been studied by Finnish and by Russian geologists (e.g. Väyrynen 1938, Gorbunov 1968, Zak et al. 1987).

\section{Previous age determinations}

Previous datings of the Pechenga rocks have been made utilizing $\mathrm{Rb}-\mathrm{Sr}, \mathrm{K}-\mathrm{Ar}$, and $\mathrm{Pb}-\mathrm{Pb}$ systems. Core samples of the Kola superdeep hole penetrating the Pechenga Series have been extensively analysed for K-Ar isotopes by E.K. Gerling and his coworkers (e.g. Kozlovsky 1987). The ages of minerals and rocks do not correlate with depth in the section and mostly vary within wide limits between $800-2100 \mathrm{Ma}$. Figures as high as 3000-13000 Ma were obtained for some samples from the lower part of the Pechenga Series due to excess of argon (Gerling et al. 1982). The $\mathrm{K}$-Ar system has obviously been disturbed during metamorphism of the Pechenga rocks and cannot be used to date the time of deposition of the supracrustal rocks. Gorokhov et al. (1982) made the same conclusion regarding the $\mathrm{Rb}-\mathrm{Sr}$ isotope analyses of phyllites from the Pilgujärvi
Suite. They considered the age of $1650 \pm 75 \mathrm{Ma}$ to represent the time of metamorphism. Skufin et al. (1986) obtained a $\mathrm{Rb}-\mathrm{Sr}$ whole rock age of $2150 \pm 125 \mathrm{Ma}$ for mugearitic-trachytic volcanics from the Kuetsjärvi Suite and regarded this figure as the time of volcanic eruptions.

The Pechenga nickel-copper deposits and their host intrusions have been intensively studied using $\mathrm{Pb}$-isotopes. Early analyses of pyrrhotite from nickel-copper ores together with model-age estimates were given by Vinogradov et al. (1959). Pushkarev et al. (1985) determined an age of $1810 \pm 80$ Ma for a garnet-diopside-vesuvianite vein cutting the ore-bearing Pilgujärvi intrusion. Pushkarev et al. (1988) have recently published $82 \mathrm{~Pb}$-isotope analyses of various samples from the Pechenga ore field including sulfide ores and whole rock samples from intrusions, pyrite ores from sedimentary country rocks, and whole rock samples of ferropicritic volcanic rocks. Taking the whole data set of metaperidotites and metagabbros, an age of $1920 \pm 100 \mathrm{Ma}$ is reported. The scattered ferropicrite analyses provide an age estimate close to $2 \mathrm{Ga}$.

\section{Sample description}

The location of the sampling sites is shown in Fig. 1. The ferropicritic samples were taken from the third level which denotes the beginning of the thickest ferropicrite-tholeiitic basalt cycle.

Samples 1748/10 and 1748/9 are from the upper part and sample $1748 / 6$ from the middle part of a layered flow outcropping near the Lake Lammas in the eastern part of the Northern Zone. Sample 1748/10 is composed mainly of clinopyroxene and magnetite. The prismatic pyroxene grains (now replaced by amphibole) are randomly oriented but magnetite grains form parallel bands. Sample 1748/9 is fine-grained rock composed almost totally of amphibole. It has a quench texture with pseudomorphs of narrow pyroxene needles indicating rapid crystallization from liquid. Sample $1748 / 6$ is a pyroxene 
cumulate with well-preserved euhedral clinopyroxene grains in a matrix composed of kaersutite needles, leucoxene pseudomorphs after skeletal magnetite, and serpentine.

Samples 1684 and $1684 / 1$ are from the lower part, 1684/4 from the middle part, and 1684/5 from the upper part of a 24-m-thick, layered flow in the Kotselvaara area. The first two samples are olivine cumulates in which olivine has totally been replaced by talc and chlorite but intervening, prismatic clinopyroxene is partially preserved. Sample 1684/4 is clinopyroxene cumulate and analogous to sample 1748/6 from the Lammas flow described above. Clinopyroxene separates were analysed from samples 1684/4 and $1684 / 5$.

Samples $1685 \mathrm{a}-\mathrm{G}$ and $1685 \mathrm{a}-\mathrm{M}$ represent respectively a globule and its matrix from the upper part of a layered flow in the Kaula area. They probably belong to the same flow as the 1684 sample series. The size of the globules vary from 2 to $18 \mathrm{~mm}$ and they comprise $20-30 \%$ of the volume of the rock (Smolkin et al. 1987). The matrix is composed of zoned, often skeletal clinopyroxene needles and prisms in a chloritealbite-orthoclase groundmass. The globules contain similar clinopyroxene grains in an albite-rich groundmass. Both the globules and matrix are characterized by the presence of kaersutite needles and leucoxene pseudomorphs after skeletal ilmenite grains.

Clinopyroxene separate SA-41 was analysed from pyroxene cumulate (plagiopyroxenite) from the middle part of the Pilgujärvi intrusion.
Fluorapatite $(3.05 \%$ F) (sample 149) was separated from a lower gabbro-pegmatite segregation in the same intrusion. Detailed information on the petrography and mineralogy of the Pilgujärvi intrusion can be found in Smolkin (1977).

One zircon separate (sample 1) was analysed from a coarse-clastic tufosilitsite lying in the middle part of the volcanic unit of the Pilgujärvi Suite near Lake Ostrovnoe. The stratigraphic position of this metasediment is about $0.5 \mathrm{~km}$ from the lower contact of the volcanic unit. The zircon sample is composed of transparent, palepink, short-columnar zircons with well-developed pyramide faces. Studies using a microprobe have revealed their complicated inner structure which resembles a microbreccia. The fragment-like type is represented by low-Ca zircon and the cementing one by high-Ca zircon which is relatively depleted in $\mathrm{Zr}$. Judging from their interrelation, they are both magmatic, high-temperature varieties, but because of their mutual impregnation, their isotopic composition could not be separately analysed. The rock also contains another, clearly different zircon generation. These zircons are rounded and turbid and yield an Archean age $(2700 \pm 90 \mathrm{Ma}$; Smolkin, unpublished data).

\section{Results}

The isotopic data produced at the Geological Survey of Finland (GSF) are given in Tables $1-3$. The analytical techniques have been described elsewhere (Huhma 1986, Vaasjoki 1989).

Table 1. U-Pb results for zircon from tufosilitsite at Pechenga.

\begin{tabular}{|c|c|c|c|c|c|c|c|c|}
\hline \multirow[t]{2}{*}{ Sample } & \multirow{2}{*}{$\begin{array}{l}\text { Size } \\
(\mathrm{mg})\end{array}$} & \multirow{2}{*}{$\begin{array}{c}{ }^{238} \mathrm{U} \\
(\mathrm{ppm})\end{array}$} & \multicolumn{3}{|c|}{ Measured } & \multicolumn{3}{|c|}{ Ratios \& ages $(\mathrm{Ma})^{*}$} \\
\hline & & & $\begin{array}{l}{ }^{206} \mathrm{~Pb} / \\
{ }^{204} \mathrm{~Pb}\end{array}$ & $\begin{array}{l}{ }^{207} \mathrm{~Pb} / \\
{ }^{204} \mathrm{~Pb}^{+}\end{array}$ & $\begin{array}{c}{ }^{208} \mathrm{~Pb} / \\
{ }^{204} \mathrm{~Pb}+\end{array}$ & $\begin{array}{c}{ }^{206} \mathrm{~Pb} / \\
{ }^{238} \mathrm{U}\end{array}$ & $\begin{array}{l}{ }^{207} \mathrm{~Pb} / \\
{ }^{235} \mathrm{U}\end{array}$ & $\begin{array}{c}{ }^{207} \mathrm{~Pb} / \\
{ }^{206} \mathrm{~Pb}\end{array}$ \\
\hline $1^{\$}$ & 1.5 & 421 & 964 & 0.1337 & 0.2238 & $\begin{array}{l}0.3165 \\
1772\end{array}$ & $\begin{array}{l}5.276 \\
1865\end{array}$ & $\begin{array}{l}0.1210 \\
1970 \pm 5\end{array}$ \\
\hline
\end{tabular}

Corrected for blank $(\mathrm{Pb}=0.5 \mathrm{ng}, \mathrm{U}=0.2 \mathrm{ng})$.

* Corrected for blank and initial common lead estimated from the whole rock data and least radiogenic sulfides (206 $\mathrm{Pb} /$ ${ }^{204} \mathrm{~Pb}=15.0,{ }^{207} \mathrm{~Pb} /{ }^{204} \mathrm{~Pb}=15.0,{ }^{208} \mathrm{~Pb} /{ }^{204} \mathrm{~Pb}=34.2$; Pushkarev et al., 1988).

$\$$ Zircons are transparent, pale pink and broken fragments. 
Table 2. $\mathrm{Pb}$ isotopic results from Pechenga.

\begin{tabular}{lrcccc}
\hline Sample & $\begin{array}{c}\mathrm{Pb} \\
(\mathrm{ppm})\end{array}$ & $\begin{array}{c}\mathrm{U} \\
(\mathrm{ppm})\end{array}$ & $\begin{array}{c}{ }^{206} \mathrm{~Pb} / \\
{ }^{204} \mathrm{~Pb}\end{array}$ & $\begin{array}{c}{ }^{207} \mathrm{~Pb} / \\
{ }^{204} \mathrm{~Pb}\end{array}$ & $\begin{array}{c}{ }^{208} \mathrm{~Pb} / \\
{ }^{204} \mathrm{~Pb}\end{array}$ \\
\hline $1684 / 1$ & 0.76 & 0.25 & 20.639 & 15.930 & 43.507 \\
$1684 / 5$ & 1.42 & 0.38 & 22.404 & 15.954 & 43.033 \\
$1685 \mathrm{a}-\mathrm{G}$ & 11.83 & 1.35 & 17.984 & 15.470 & 37.859 \\
$1685 \mathrm{a}-\mathrm{M}$ & 5.58 & 1.57 & 21.002 & 15.813 & 40.854 \\
$1748 / 9$ & 6.26 & 0.52 & 17.158 & 15.359 & 36.926 \\
$1748 / 10$ & 1.72 & 0.84 & 33.693 & 17.346 & 55.081 \\
149 (apatite) & & & 37.41 & 17.88 & 54.81 \\
\hline
\end{tabular}

Errors in measured ratios are $0.15 \%$.

Table 3. Sm-Nd results from Pechenga.

\begin{tabular}{llrrrc}
\hline Sample & $\$$ & $\begin{array}{c}\text { Sm } \\
(\mathrm{ppm})\end{array}$ & $\begin{array}{c}\mathrm{Nd} \\
(\mathrm{ppm})\end{array}$ & $\begin{array}{l}{ }^{147} \mathrm{Sm} / \\
{ }^{144} \mathrm{Nd}^{*}\end{array}$ & $\begin{array}{c}{ }^{143} \mathrm{Nd} / \\
{ }^{144} \mathrm{Nd}^{+}\end{array}$ \\
\hline 1684 & wr & 3.81 & 18.67 & 0.1234 & $0.511746 \pm 26$ \\
$1684 / 1$ & wr & 3.09 & 13.72 & 0.1362 & $0.511896 \pm 52$ \\
$1684 / 4$ & cpx & 3.12 & 9.58 & 0.1968 & $0.512713 \pm 26$ \\
$1684 / 5$ & wr & 4.50 & 19.81 & 0.1373 & $0.511950 \pm 21$ \\
$1684 / 5$ & cpx & 2.99 & 9.23 & 0.1962 & $0.512715 \pm 30$ \\
$1748 / 9$ & wr & 6.89 & 31.84 & 0.1309 & $0.511862 \pm 25$ \\
$1748 / 6$ & wr & 4.65 & 18.73 & 0.1502 & $0.512124 \pm 21$ \\
SA-41 & cpx & 4.65 & 14.06 & 0.2001 & $0.512787 \pm 40$ \\
149 & apatite & 296.00 & 1322.00 & 0.1353 & $0.511947 \pm 24$ \\
\hline
\end{tabular}

* Error is $0.4 \%$. The concentrations were determined from liquid aliquots.

+ Ratios normalized to ${ }^{146} \mathrm{Nd} /{ }^{144} \mathrm{Nd}=0.7219$. Reported errors are $20 \sigma_{\mathrm{m}}$.

$\$ \mathrm{wr}=$ whole rock, $\mathrm{cpx}=$ clinopyroxene.

\section{$\mathrm{U}-\mathrm{Pb}$}

Only one, $90 \%$ concordant analysis on transparent zircon from tufosilitsite is available at the moment. It has a $207 \mathrm{~Pb} / 206 \mathrm{~Pb}$-age of $1970 \pm 5$ Ma (Table 1). Providing that the zircon comes from a single magmatic population, this is a minimum age for the zircon.

\section{$P b-P b$}

Using only the analyses made at GSF, the six picritic samples and one apatite from the Pilgujärvi intrusion give an age of $1982 \pm 110 \mathrm{Ma}$ (MSWD =48). Excluding the analysis of sample $1684 / 1$, which is an olivine cumulate that is extensively serpentinized and hence chemically somewhat disturbed, the age becomes $2004 \pm 55$ Ma (MSWD = 12, Fig 2). Without apatite and $1684 / 1$, the figure is $1955 \pm 43 \mathrm{Ma}$. The data plot below average global lead evolution curves, and thus the initial $\mathrm{Pb}$-isotopic composition must have had a relatively low ${ }^{207} \mathrm{~Pb} /{ }^{204} \mathrm{~Pb}$ ratio when compared with the coeval average terrestrial lead (Fig. 2). This means that for a long period before the extrusion, lead isotopic evolution took place in a reservoir which had $\mathrm{U} / \mathrm{Pb}$ ratio lower than the global average. This reservoir can be characterized by $\mu\left({ }^{238} \mathrm{U} /{ }^{204} \mathrm{~Pb}\right)$ which has been

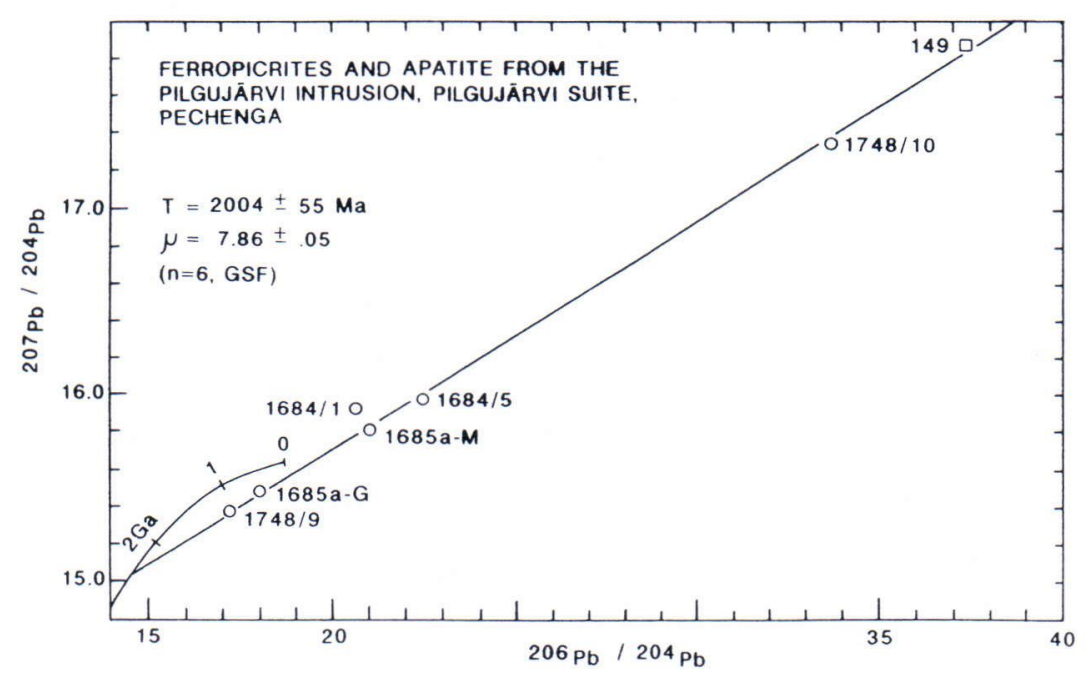

Fig. 2. ${ }^{207} \mathrm{~Pb} / 204 \mathrm{~Pb}$ vs. ${ }^{206} \mathrm{~Pb} / 204 \mathrm{~Pb}$ diagram for ferropicritic whole rocks samples (circles) and apatite separate (square) from the Pilgujärvi intrusion. Excluding one altered picrite sample $(1684 / 1)$, the regression line defines an age of $2004 \pm 55$ Ma $(2$, MSWD = 12). The initial ratio $(\mu)$ shown for the chord represents a single stage evolution from the Canyon Diablo lead. The average terrestrial growth curve after Stacey and Kramers (1975) is shown for comparison. 
Fig. 3. Nd isochron diagram. Whole rocks (wr) of and clinopyroxenes (cpx) from Pechenga ferropicrites (circles), and fluorapatite and clinopyroxene from the Pilgujärvi intrusion (squares) define an age of $1990 \pm 66 \mathrm{Ma}(2 \sigma$ MSWD $=1.2$ ). The initial $\varepsilon_{\mathrm{Nd}}$ value is $+1.6 \pm 0.4$. The vertical lines in the symbols represent $2 \sigma$ errors.

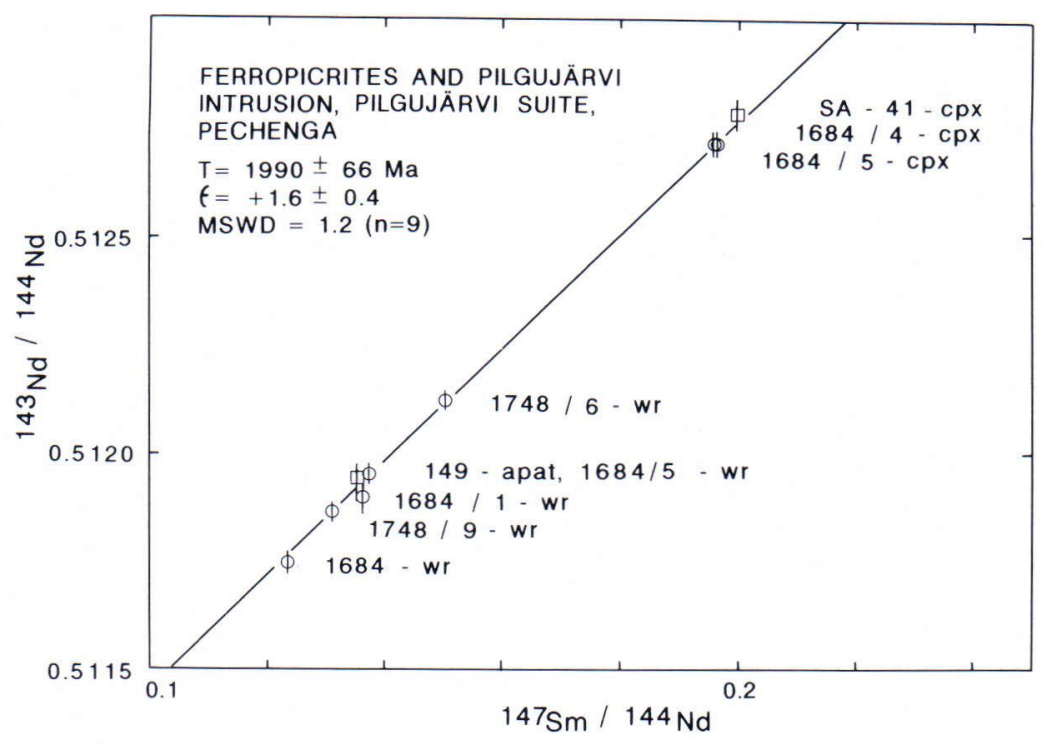

calculated from the Canyon Diablo lead using a single stage evolution and $\mathrm{T}_{0}=4570 \mathrm{Ma}$. Our isotopic analyses yield a $\mu$ value of 7.86 , whereas a $\mu$ value of 7.75 can be calculated on the basis of data given by Pushkarev et al. (1988).

\section{$S m-N d$}

The Sm-Nd data on five ferropicrites and two clinopyroxene fractions define an age of $1990 \pm 66 \mathrm{Ma}$ with an initial $\varepsilon_{\mathrm{Nd}}$ value of $+1.6 \pm 0.4$ (Table 3 and Fig. 3 ). The result would be exactly the same if analyses on clinopyroxene and apatite fractions from the Pilgujärvi intrusion were included.

\section{Discussion}

The $\mathrm{Pb}$ isotopic data analysed at the Geological Institute in Apatity (GI) provide ages similar to our results (Pushkarev et al. 1988). Eight ferropicritic samples from the lower part of the volcanic unit of the Pilgujärvi Suite yield $\mathrm{Pb}-\mathrm{Pb}$ age of $2032 \pm 85 \mathrm{Ma}$. Pushkarev et al. (1988) also included in their calculation two samples from the "productive unit» representing a tuff and a layered flow and two pillow lava samples from the Tominga Series in the Imandra-Varzuga Zone, and obtained a younger age of $1995 \pm 80$ Ma. The justification of including the Tominga samples is based on their similarity in stratigraphic position and geochemical composition to those of volcanics of the Pilgujärvi Suite (Smolkin and Dain 1985). Hanski and Smolkin (1989) showed that the Tominga picrites are similar in chemical composition (including REE) to the Pechenga ferropicrites and clearly differ from picrites of the South Pechenga Series and the Umba Suite in their $\mathrm{MgO}-\mathrm{FeO}-\mathrm{Al}_{2} \mathrm{O}_{3}$ relations. Although any meaningful age cannot be calculated on the basis of the two Tominga samples, their isotopic composition is compatible with a common origin for both the Pechenga and Tominga ferropicrites.

Lead isotopic data for ferropicritic samples from both GSF and GI show scatter in excess of experimental error most probably caused by secondary processes following eruption. This makes the method less reliable for dating. Furthermore, some data points have been ambigu- 
ously rejected in order to obtain reasonable errors. Nevertheless, all three methods used during this study (the $\mathrm{U}-\mathrm{Pb}$ zircon, $\mathrm{Pb}-\mathrm{Pb}$ and $\mathrm{Sm}-$ $\mathrm{Nd}$ ) yield reasonable consistent ages of about 1970-2000 Ma which are considered to define the time of extrusion of the ferropicrites. The younger zircon population in tufosilitsites is probably derived from the upper part of a ferropicritic pillow lava or layered flow. This inference is based on the observations of zones of submarine weathering (halmyrolysis) in ferropicrites and the similarity of REE characteristics (excluding $\mathrm{Eu}$ ) of ferropicrites and tufosilitsites.

Pushkarev et al. (1988) report $\mathrm{Pb}$ isotopic analyses on 32 whole rock samples from the Pechenga gabbro-wehrlite intrusions. On the basis of the whole data set, they have calculated an age of $1920 \pm 100 \mathrm{Ma}$. Excluding the three most radiogenic (anomalous) data points and including our analysis of the Pilgujärvi apatite (Table 2), an age of $1970 \pm 70 \mathrm{Ma}$ can be calculated. The figure for the Pilgujärvi intrusion solely would be $1979 \pm 114 \mathrm{Ma}$ (four whole rocks and our apatite sample). Seven analyses on the Kierdzhipori intrusion yield $1963 \pm 52 \mathrm{Ma}$ (two analyses excluded), whereas Pilgujärvi and Kierdzhipori data combined would give $2001 \pm 77 \mathrm{Ma}$. Thus both $\mathrm{Sm}-\mathrm{Nd}$ and $\mathrm{Pb}-\mathrm{Pb}$ isotopic data suggest that the gabbro-wehrlite intrusions and the ferropicrites are coeval within analytical error.

Based on major and trace element geochemistry, Hanski and Smolkin (1989) have demonstrated that the parental magma of the Ni-bearing intrusions is similar to ferropicrite. This is compatible with the Sm-Nd isotopic results, since the initial $\varepsilon_{\mathrm{Nd}}$ values for the picrites and intrusions are the same within analytical error (Fig. 3). The $\mathrm{Pb}$ isotopic data on the intrusions provide a source value slightly higher compared to the picrites. This could be due to the addition of radiogenic crustal lead e.g. by fluids during the cooling of intrusions. However considering the scatter of the data, it is difficult to state anything definite about the origin of $\mathrm{Pb}$ in the intrusions. The $\mathrm{Pb}$ isotopic data do not contradict the view of a com- mon origin for the ferropicritic volcanics and the gabbro-wehrlite intrusions.

In this connection, it is interesting to note that Gorbunov et al. (1989) have recently reported a new finding of a 3.2-m-thick ferropicritic flow with a massive, 0.45 -m-thick $\mathrm{Ni}-\mathrm{Cu}$ sulfide ore deposit at its base. This discovery provides strong evidence for the operation of ore forming processes during the ferropicritic volcanism. However, studies on the contact relations by one of us (V.F.S.) suggest that in this case we are dealing with a shallow level sill rather than a lava flow.

The Pechenga ferropicrites form a geochemically distinct, primitive magma type. They are characterized by high total iron content exceeding $14 \%$ (calculated as $\mathrm{FeO}$ ), low $\mathrm{Al}_{2} \mathrm{O}_{3} / \mathrm{TiO}_{2}$, and strong LREE enrichment (Hanski and Smolkin, 1989). These features are considered to be inherited from the mantle source region which was enriched in iron and LREE (Hanski 1989). The isotopic results provide further constraints to the origin of these rocks. The whole rock $\mathrm{Pb}$ isochron passes through the most primitive sulfide $\mathrm{Pb}$ isotopic composition $\left({ }^{207} \mathrm{~Pb} /{ }^{204} \mathrm{~Pb}=15.0\right.$, ${ }^{207} \mathrm{~Pb} /{ }^{204} \mathrm{~Pb}=15.0$, Pushkarev et al. 1988) and gives an initial $\mathrm{Pb}$ isotopic composition which has a relatively low ${ }^{207} \mathrm{~Pb} /{ }^{204} \mathrm{~Pb}$ ratio compared with the average for terrestrial lead at $2 \mathrm{Ga}$ (Fig. 2). The initial $\mathrm{Pb}$ ratio is very close to the mantle ratios derived from the plumbotectonics model by Zartman and Doe (1981). Strongly contrasting to the slighly older Runkaus basalts from the Peräpohja area, northern Finland (Huhma et al. 1990), these results suggest that the ferropicrites were not contaminated by old radiogenic crustal lead. Neither is there any sign of contamination in the major or trace element chemistry of the ferropicrites. Thus the initial $\varepsilon_{\mathrm{Nd}}(1990)$ value of +1.6 should represent $\mathrm{Nd}$ isotopic composition of the mantle source. This suggests that at some stage the source had an evolution in a LREE depleted environment. However by the time of extrusion, the source was already strongly enriched in LREE. The data may give some con- 
straints for the timing of this enrichment. Since the ferropicrites are high-MgO magmas produced by a relatively high-degree of melting in which garnet was probably not a residual phase (Hanski 1989), their Sm/Nd ratio is close to that of their source region. One can thus calculate the TDM model ages for the enriched samples, which in this case are c. $2.2 \mathrm{Ga}$. Providing that no fractionation of $\mathrm{Sm} / \mathrm{Nd}$ took place in the source between 2.2 and $2.0 \mathrm{Ga}$, the $2.2 \mathrm{Ga}$ age corresponds to the time when the source of the ferropicrites would have had a $\mathrm{Nd}$ isotopic composition equivalent to the model depleted mantle as expressed by DePaolo (1981).

In regional stratigraphic correlation schemes, the Kolasjoki Suite belongs to the Upper Jatulian (e.g. Zagorodnyi 1980). The overlying Pilgujärvi Suite has traditionally been correlated with the Suisaarian formations in southern Karelia (e.g. Svetov 1976), one reason being the presence of picritic volcanics in both units. Later, after the combination of the Zhaonezhye and Suisaarian into the Ludicovian (Kratts et al. 1984), the Pilgujärvi Suite has been assigned to the Ludicovian (e.g. Predovskii et al., 1987). Our isotopic results are compatible with the suggestion made by Meriläinen and Sokolov (1981) that the upper age limit of the Jatulian rocks is about 2000 Ma. In contrast, there is a discrepancy with the following statement by Zagorodny et al. (1986): "the zircons from albite diabase dykes which serve as feeders of Zhaonezhye and possibly Suisarian volcanites are dated at $2100-2200$ Ma».

It is interesting to compare the Sm-Nd isotopic data from Pechenga with published isotopic results from other greenstone belts in northern Norway, Sweden and Finland. Krill et al. (1985) have shown that the Archean age for the Karasjok greenstone belt suggested by some authors was incorrect and published a Sm-Nd whole rock age of $2085 \pm 85$ Ma for 8 komatiite samples $\left(\varepsilon_{\mathrm{Nd}}+4.1\right)$ from the Bakkilvarri Formation. Although the samples have a good fit to the regression line, the precision of the age is somewhat doubtful. This is because the samples used in the isochron construction form two populations: the one has high $\mathrm{MgO}(23-27 \%)$, low $\mathrm{TiO}_{2}$ $(0.5-0.7 \%)$, and is LREE-depleted whereas the other is lower in $\mathrm{MgO}(16-18 \%)$ and enriched in $\mathrm{TiO}_{2}(1.2-1.8 \%)$ and other incompatible elements (LREE-enriched). These two types of komatiites can not be related to each other by low-pressure crystal fractionation and the possibility of their derivation from multiple sources can not be ruled out.

The Jatulian tholeiitic volcanics of the Jouttiaapa Formation from the Peräpohja schist belt in Finland appear to be slightly older than the Pechenga ferropicrites. Huhma et al. (1990) have obtained an age of $2090 \pm 70 \mathrm{Ma}$ and an initial $\varepsilon_{\mathrm{Nd}}$ value of $+4.2 \pm 0.5$ for these volcanics. This figure together with the above mentioned $\mathrm{Nd}$ values for the Karasjok komatiites and the +3.6 value reported by Skiöld and Cliff (1984) for greenstones in the Kiruna area clearly show that the source region of the Pechenga ferropicrites $\left(\varepsilon_{\mathrm{Nd}}+1.6 \pm 0.4\right)$ was different (less depleted) than the mantle from which the komatiites in northern Norway and tholeiites in the Kiruna and Peräpohja area were derived. This gives evidence that during the early Proterozoic there existed geochemically distinct subcontinental mantle reservoirs, which remained unmixed for a long period of time $(<200 \mathrm{Ma})$.

Magmatic activity on the cratonic terrain at $\mathrm{c}$. $2.0 \mathrm{Ga}$ is further corroborated by U-Pb zircon ages on felsic porphyries and diabases in central Finnish Lapland (Hiltunen 1982, Kouvo 1984) which might imply more widespread coeval volcanism there. Also some gabbros c. $100 \mathrm{~km}$ west of Pechenga are temporally close to ferropicrites (about $1.95 \mathrm{Ga}, \mathrm{U}-\mathrm{Pb}$ zircon, Meriläinen 1976). This calc-alkaline magmatism within the Archaean craton of the Baltic Shield (Barbey et al. 1984) seem to have occurred after the »riftrelated» ferropicritic volcanism at Pechenga.

On the southwestern margin of this craton, the Jormua and Outokumpu ophiolites seem to be roughly coeval with the Pechenga ferropicrites 
and Ni-bearing intrusions. Gabbros associated with these ophiolites yield a U-Pb zircon age of ca. 1.96 Ga (Kontinen, 1987; Huhma, 1986). Lead isotopes provide another interesting similarity. The isotopic composition of Outokumpu galena (Vaasjoki 1981) can be very close to the initial lead isotopic composition inferred for the Pechenga ferropicrites. Geochemically ferropicrites and ophiolites are, however, strictly unrelated. Furthermore, although the tholeiitic basalts of the Pilgujärvi Suite have REE characteristics resembling those of MORB, they are much more iron-rich than MORB and differ markedly in this respect from the basalts of the Jormua ophiolite complex (Kremenetsky and Ovchinnikov 1986, Kontinen, 1987).

Acknowledgements. We are indebted to the staff of the isotope laboratory of GSF for assisting in analytical work and to Torbjörn Skiöld for critically reviewing the manuscript.

\section{References}

Bakushkin, Ye.M., Zhuravlev, D.Z., Bayanova, T.B. \& Balashov, Yu.A., 1990. Mountain Generalskaya. In F.P. Mitrofanov and Yu.A. Balashov (eds.) Geochronology and Genesis of Layered Basic Intrusions, Volcanites and Granite-Gneisses of the Kola Peninsula. The USSR Academy of Sciences, Apatity, 14-15 (in press).

Barbey, P., Convert, B, Moreau, B., Capdevila, R. \& Hameurt, J., 1984. Petrogenesis and evolution of an early Proterozoic collisional orogenic belt: the granulite belt of Lapland and the Belomorides (Fennoscandia). Bull. Geol. Soc. Finland 56, 161-188.

DePaolo, D.J., 1981. Neodymium isotopes in the Colorado Front Range and crust-mantle evolution in the Proterozoic. Nature 291, 193-196.

Gerling, E.K., Koltsova, T.V.\& Dyk, G.G., 1982. Anomalous contents of radiogenic isotope of argon and germanium in minerals and rocks of the Pechenga Complex (Kola Peninsula). In E.K. Gerling, O.A. Levchenkov (ed-inchiefs) Methodological Problems in Nuclear Geology. Nauka, Leningrad, 5-21 (in Russian).

Gorbunov, G.I., 1968. Geology and Genesis of the Pechenga Ni-Cu Sulfide Deposits. Nedra, Moscow, 352 p. (in Russian).

-, Korchagin, A.U. \& Kutyavin, E.P., 1989. Ore content of the Pechenga picrites. Dokl. Akad. Nauk SSSR 304, 1205-1208 (in Russian).

Gorokhov, I.M., Varshavskaya, E.S., Kutyavin, E.P. \& Melnikov, N.N., 1982. Rb-Sr dating of low-grade metamorphics in the U.S.S.R. Precambrian Res. 18, 145-156.

Gruau, G., Chauvel, C. \& Jahn, B.M., 1990. Anomalous SmNd ages for the early Archean Onverwacht Group Volcanics. Significance and petrogenetic implications. Contrib. Mineral. Petrol. 104, 27-34.

Hanski, E., 1989. Anomalous mantle source of Early Proterozoic Pechenga ferropicrites, Kola Peninsula. 28th International Geological Congress, Abstracts 2, 25-26.

—, Smolkin, V.F., 1989. Pechenga ferropicrites and other early Proterozoic picrites in the eastern part of the Baltic Shield. Precambrian Res. 45, 63-82.

Hiltunen, A., 1982. The Precambrian geology and skarn iron ores of the Rautuvaara area, northern Finland. Geol. Surv. Finland, Bull. 318, 133 p.

Huhma, H., 1986. Sm-Nd, U-Pb and $\mathrm{Pb}-\mathrm{Pb}$ isotopic evidence for the origin of the Early proterozoic Svecokarelian crust in Finland. Geol. Surv. Finland, Bull. 337, 48p.

-, Cliff, R.A., Perttunen, V. \& Sakko, M., 1990. Sm-Nd and $\mathrm{Pb}$-isotopic study of mafic rocks associated with early Proterozoic continental rifting: The Peräpohja Schist Belt in northern Finland. Contrib. Mineral. Petrol. 104, $369-379$.

Kontinen, A., 1987. An early Proterozoic ophiolite - the Jormua mafic-ultramafic complex, northern Finland. Precambrian Res. 35, 313-341.

Kouvo, O., 1984. Isotopical studies. Annual Report of the Petrological Department of the Geological Survey of Finland, 1983, p. 39-51. Geological Survey of Finland, Espoo (in Finnish).

Kozlovsky, Ye.A. (ed.), 1987. The Superdeep Well of the Kola Peninsula. Springer-Verlag, Berlin Heidelberg, $558 \mathrm{p}$.

Kratts, K.O., Negrutsa, V.Z., Sokolov, V.A., Bogdanov, Yu.B., Gaskelberg, V.G., Zagorodnyi, V.G., Negrutsa, T.F., Semikhatov, M.A., Shurkin, K.A., 1984. New data on the investigation of the Precambrian stratigraphy in the Soviet part of the Baltic Shield. Sov. Geol. 7, 105-118 (in Russian).

Kremenetsky, A.A. \& Ovchinnikov, L.N., 1986. Geochemistry of Deep Rocks. Nauka, Moscow, 262 p. (in Russian).

Krill, A., Bergh, S., Lindahl, I., Mearns, E.W., Often, M., Olerud, S., Sandstad, J.S., Siedlecka, A. \& Solli, A., 1985. Rb-Sr, U-Pb and $\mathrm{Sm}-\mathrm{Nd}$ isotopic dates from Precambrian rocks of Finnmark. Nor. Geol. Unders. 403, $37-54$.

Meriläinen, K., 1976. The granulite complex and adjacent rocks in Lapland, northern Finland. Geol. Surv. Finland, Bull. 281, 129 p. 
Meriläinen, K. \& Sokolov, V.A., 1981. Some attainments and problems relating to the geology of the Jatulian formations in Finland and Soviet Karelia. In K. Puustinen (ed.) Geological, Geochemical and Geophysical Investigations in the Eastern Part of the Baltic Shield. The Committee for Scientific and Technical Co-operation between Finland and the Soviet Union, Helsinki, 9-18.

Predovskii, A.A., Fedotov, Zh.A. \& Akhmedov, A.M., 1974. Geochemistry of the Pechenga Complex. Nauka, Leningrad, 139 p. (in Russian).

-, Melezhik, V.A., Bolotov, V.I., Fedotov, Zh.A., Basalaev, A.A., Kozlov, N.E., Ivanov, A.A., Zhangurov, A.A., Skufin, P.K. \& Lyubtsov, V.V., 1987. Volcanism and Sedimentology of the Precambrian in the Northeastern Part of the Baltic Shield. Nauka, Leningrad, 185 p. (in Russian).

Pushkarev, Yu.D., Kravchenko, E.V. \& Shestakov, G.I., 1978. Precambrian Geochronological Markers in the Kola Peninsula. Nauka, Leningrad. 136 pp. (in Russian).

-, Kravchenko, M.P. \& Kravchenko, E.V. 1985. Geochemistry of lead and sulfur isotopes and the problem of the origin of copper-nickel sulfide mineralization. In New Data on the Nickel Deposits of the Kola Peninsula. Geol. Inst. Kolsk. Filial AN SSSR, Apatity, 72-88 (in Russian).

-, Ryungenen, G.I., Smolkin, V.F. \& Shurkina, L.K., 1988. $\mathrm{Pb}$ isotope geochemistry and the generation of nickelbearing basic-ultrabasic rocks in the Kola Peninsula. In Yu.A. Shukolyukov (ed-in-chief) Isotope Geology and Processes of Ore Formation. Nauka, Leningrad, 150-166 (in Russian).

Skufin, P.K. , Pushkarev, Yu.D. \& Kravchenko, M.P., 1986. Volcanics of the mugearite-trachyte formation in the Pechenga volcanotectonic paleodepression. Izv. Akad Nauk SSSR, Ser. Geol. 1, 18-29 (in Russian).

Skiöld, T. \& Cliff, R.A., 1984. Sm-Nd and U-Pb dating of Early Proterozoic mafic-felsic volcanism in northernmost Sweden. Precambrian Res. 26, 1-13.

Smolkin, V.F., 1977. Petrology of the Pilgujärvi Ore-bearing Intrusion. VINITI, No. 2114-77, 216 p. (in Russian).

-, 1985. Vulkano-plutonic associations in the Lower Proterozoic belts and their ore contents. In T.I. Ivanova (edin-chief) Petrology and Criteria for Evaluation of Ore Content of Precambrian Basic-Ultrabasic Formations in the Karelia-Kola Region. Kolskii Filial AN SSSR, Apatity, 34-50 (in Russian).

—, \& Dain, A.D., 1985. Gabbro-wehrlite formation in the
Karelian Imandra-Varzuga Zone. Sov. Geol. 12, 94-105 (in Russian).

-, Borisov, A.E. \& Marakushev, A.A., 1987. Signs of differentiation and immiscibility of picrito-basaltic liquids in Pechenga. Dokl. Akad. Nauk SSSR 294, 669-673 (in Russian).

Stacey, J.S. \& Kramers, G.D., 1975. Approximation of terrestrial lead isotope evolution by a two-stage model. Earth Planet. Sci. Lett. 26, 207-221.

Svetov, A.P., 1976. Basaltic platform volkanism in the eastern part of the Baltic Shield. In V.S. Kulikov \& V.A. Sokolov (eds-in- chief) Precambrian Volcanism. Karelskii Filial AN SSSR, Petrozavodsk,46-53 (in Russian).

Vaasjoki, M., 1981. The lead isotopic composition of some Finnish galenas. Geol. Surv. Finland, Bull. 316, 30 p.

-, 1989. $\mathrm{Pb}$ and $\mathrm{S}$ isotopic studies on the Rauhala $\mathrm{Zn}-\mathrm{Cu}$ $\mathrm{Pb}$ sulphide deposit and its environment. Geol. Surv. Finland, Spec. Paper 11, 59-65.

Väyrynen, H., 1938. Petrologie des Nickelerzfeldes Kaulatunturi-Kammikivitunturi in Petsamo. Bull. Comm. géol. Finlande 116, 198 p.

Vinogradov, A.P., Tarasov, L.S. \& Zykov, S.I., 1959. Isotopic composition of leads from the ores of the Baltic shield. Geochemistry, 7, 689-749.

Wasserburg, G.J., 1963. Diffusion processes in lead-uranium systems. J. Geophys. Res. 68, 4823-4846.

Zagorodnyi, V.G., 1980. Jatulian geology of the Kola Peninsula. In A. Silvennoinen (ed.) Jatulian Geology in the Eastern Part of the Baltic Shield. The Committee for Scientific and Technical Co-operation between Finland and the Soviet Union, Rovaniemi, 221-238.

Zagorodny, V.G., Negrutsa, V.Z. \& Sokolov, V.A., 1986. Stratigraphy of Karelian deposits in the Karelian-Kola region. In V.A. Sokolov and K.I. Heiskanen (eds.) Early Proterozoic of the Baltic Shield. Karelskii Filial AN SSSR, Petrozavodsk, 199-205.

Zak, S.I., Makarov, V.N., Kochnev-Pervukhov, V.I., Proskuryakov, V.V., Zaskind, E.S., Batashev, E.V. \& Kolesnikov, G.P., 1982. Geology, Magmatism and Ore Formation in the Pechenga Ore Belt. Nedra, Leningrad, 112 p. (in Russian).

Zartman, R.E. \& Doe, B.R., 1981. Plumbotectonics - the model. Tectonophysics $75,135-162$.

Reiceived May 19, 1990

Revision accepted October 27, 1990 